\title{
Status assessment of lampreys in Natura 2000 network in Lithuania
}

\author{
Robertas Staponkus*, \\ Vytautas Kesminas \\ Nature Research Centre, \\ Akademijos str. 2, \\ LT-08412 Vilnius, \\ Lithuania
}

The two lamprey species, European river lamprey Lampetra fluviatilis L. and European brook lamprey L. planeri Bloch, which inhabit Lithuanian rivers are of conservation concern. They are considered either Vulnerable, Critically Endangered, or even Extinct in different regions of Europe. Migration obstacles and consequent habitat loss and population fragmentation are probably the most widespread and significant factors contributing to the current status. Therefore, all member states are obliged to designate Special Areas of Conservation (SACs). This study assessed the conservation status of L. fluviatilis and L. planeri in 16 Proposed Sites of Community Interest (pSCIs) for lamprey conservation in Lithuania. Lamprey ammocoete surveys were conducted at 41 sites following the established national protocol. In particular, we compare historical and recent data of lampreys in Lithuanian rivers, discuss the factors that contributed most to their decline and recommend conservation measures that may contribute to their recovery.

Key words: river lamprey, brook lamprey, lampetra, pSCI, NATURA 2000

\section{INTRODUCTION}

The Baltic Sea basin is represented by one lamprey family Petromyzontidae, which is dominant in all Northern Hemisphere and include three genus Petromyzon, Lampetra and Eudontomyzon (Renaud, 2011). In Lithuanian watersheds there are recorded Lampetra genus representatives ac-

\footnotetext{
* Corresponding author. E-mail: robertas.staponkus@gmail.com
}

counting for two closely related species of river lamprey Lampetra fluviatilis and brook lamprey Lampetra planeri as well as Petromyzon genus represented by sea lamprey Petromyzon marinus (Red Data Book of Lithuania, 2007). Lampetra genus lampreys are common in Lithuanian territorial waters contrariwise to very rare sea lampreys. There are confirmed reports about sea lampreys captured in the Curonian Lagoon, latest dated from 1961 (Gaigalas, 2001). How- 
ever, sea lamprey did not appear in commercial catch reports available since 1887 (Thiel et al., 2009) and is considered occasional migrant in national waters. Lampetra fluviatilis is restricted to Lithuanian watersheds with accessible rivers (Kesminas and Švagždys, 2010). Due to larger body size L. fluviatilis is the only species that has economic value in the Baltic Sea region and is on various scale exploited around the Baltic Sea. In Lithuania river lamprey fishery is managed by quota system with an annual quota of 7 tonnes in two localities.

Both lampreys present in Lithuanian water bodies are of conservation concern in Europe and are listed on Annex II of the European Union (EU) Habitats Directive (92/43/EEC). In different regions of Europe they are considered Vulnerable or Critically Endangered or even Extinct. The deterioration of lamprey status is mostly associated with loss of habitat and population fragmentation. The directive obliges all member states to designate Special Areas of Conservation (SACs) for the protection of Annex II species and ensure their favourable conservation status.

The decline of lamprey populations in Lithuanian rivers is caused by migration obstacles (dams and weirs) that make a significant impact on anadromous lampreys causing an estimated loss of approx. $70 \%$ of accessible rivers and even bigger number of habitats (Gailiušis et al., 2001). However, globally these 3 species are considered of Least Concern according to the International Union for Conservation of $\mathrm{Na}$ ture (IUCN) Red List of Threatened Species (Freyhof and Kottelat, 2011 a, b, c). On the scale of the Baltic Sea basin, L. fluviatilis is considered Near Threatened (A2bd) and P. marinus is considered Vulnerable (C2a(i)) (HELCOM, 2013).

NATURA 2000 network covers an area of 826868 hectares, which is about $13 \%$ of the country of which Proposed Sites of Community Interest (406) occupy a total area of 651625 ha. For a complex of protected species, including river and brook lampreys, 25 SCIs with a total area of 67763 ha are proposed. Ten on them are proposed for the conservation of $L$. planeri and the rest for L. fluviatilis. The selected SACs have to include the geographical range of the species and include a range of high-quality river types in which lampreys reside. Under ideal conditions, these sites should hold healthy populations of $L$. fluviatilis and L. planeri with clear water and suitable areas of gravel, silt or sand for spawning. The proposed sites generally include river sections but not whole catchments providing a limited range of habitat features required by the species.

In this paper we highlight lamprey conservation status, the distribution in Proposed Sites of Community Interest in Lithuania and also discuss the factors that contributed most to their decline and recommend conservation measures that may contribute to their recovery.

\section{MATERIALS AND METHODS}

The survey took place during the period April-August 2008 and May-October 2012 and focused on juvenile lampreys known as ammocoetes. Ammocoetes sampling procedure followed the guidelines of the Lithuanian Ministry of Environment; ammocoetes were collected by shovelling a $1 \mathrm{~m}^{2}$ netted area (Kesminas et al., 2009a). The sampling was carried out in optimal ammocoetes habitats at a bankside of the river or backflow sections, with prevailing fine sediment and visible aggregation of detritus (Harvey and Cowx, 2003; Torgersen and Close, 2004). All ammocoetes were anaesthetised with 2-diphenylethanol $0.3 \mathrm{ml} / \mathrm{l}$, the total length measured (TL, $\mathrm{mm}$ ), and released after recovery.

As Kaunas Hydroelectric Power Plant is an impassable obstacle for fish migration, we assume upper reaches of the Nemunas basin to be entirely inhabited by stationary Lampetra planeri. All other freely accessible rivers and river sections are inhabited entirely by L. fluviatilis or by co-occurring both $L$. planeri and L. fluviatilis populations. In such areas due to the lack of morphological differences ammocoetes were classified as Lampetra sp. (Gardiner, 2003). 


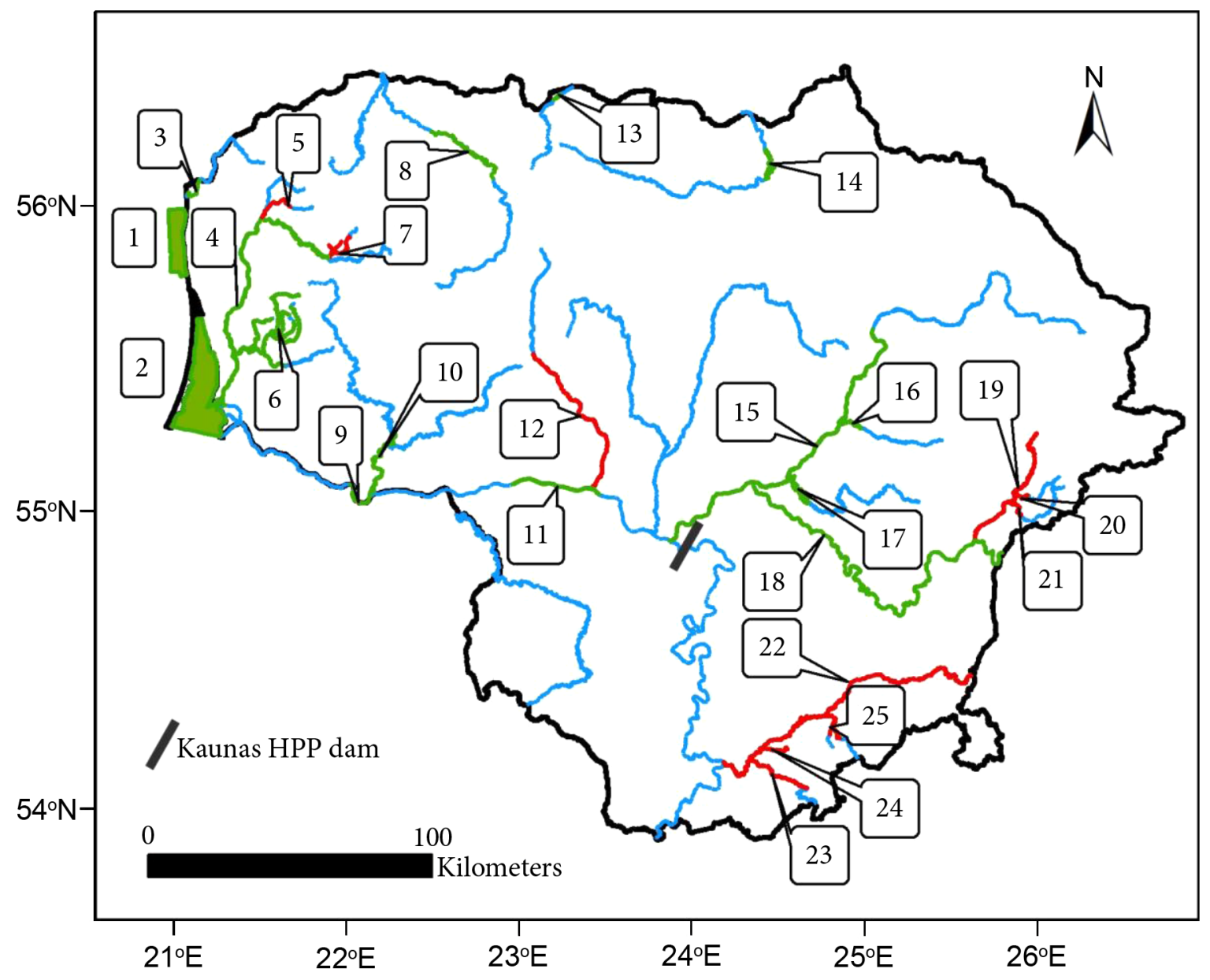

Figure. Proposed Sites of Community Interest for lamprey protection in the Lithuanian territory. Green colour indicates river sections and areas established for river lamprey protection and red colour indicates river sections of brook lamprey protection. Numbers indicate distinct areas: 1 . Baltic Sea coastal waters; 2. Curonian Lagoon; 3. River Šventoji; 4. River Minija; 5. Rivers Salantas and Blendžiava; 6. Rivers Veiviržas and Šalpė; 7. River Sausdravas; 8. River Venta; 9. River Nemunas; 10. River Jūra; 11. River Nemunas; 12. River Dubysa; 13. River Švètė; 14. River Mūša; 15. River Šventoji; 16. River Siesartis; 17. River Širvinta; 18. River Neris; 19. River Žeimena; 20. River Saria; 21. River Mera; 22. River Merkys; 23. River Üla; 24. River Derežna; 25. Rivers Verseka and Pasgrinda

\section{RESULTS AND DISCUSSION}

A total of 41 sampling sites were examined covering 16 pSCIs (Figure). The mean population densities of $L$. fluviatilis and L. planeri ammocoetes in sites varied from $0 \mathrm{per} / \mathrm{m}^{2}$ to $46 \mathrm{per} / \mathrm{m}^{2}$. As the majority of pSCIs cover river sections rather than whole catchments, they were evaluated at an optimal habitat perspective. The national targets set for com- pliance with favourable conservation status under the Habitats Directive are $>10$ per $/ \mathrm{m}^{2}$ for $L$. planeri ammocoetes and correspond to the targets outlined by Harvey and Cowx (2003). On the other hand, the national targets set for L. fluviatilis ammocoetes are $>60 \mathrm{per} / \mathrm{m}^{2}$ (Minister of Environment..., 2008). L. fluviatilis target is several times higher than that proposed by Harvey and Cowx (2003) and that is generally applied across Europe. This target is 
in line with historical data. Although such data on the distribution and densities of $L$. fluviatilis ammocoetes in Lithuania is scarce and limited to an individual study of Mackevičius (1969) it is obvious that over last 40 years lamprey population in the Lithuanian watersheds has faced a decline. In his study Mackevičius (1969) collected data from 11 rivers and estimated average density of ammocoetes that was $66.5 \pm 14.9( \pm \mathrm{CI})$.

The conservation status was rated as 'Favourable' only in one of pSCIs - the Salantas and Blendžiava Rivers (Table). This pSCI is established for L. planeri protection, although the communal spawning of both L. fluviatilis and L. planeri is annually observed in redds there.

Table. Assessment of Conservation Status of lampreys (Lampetra sp.) and summary statistics for surveyed pSCIs

\begin{tabular}{|c|c|c|c|c|c|c|}
\hline $\begin{array}{c}\text { Proposed Site } \\
\text { of Community } \\
\text { Interest code } \\
\text { (Figure, ref. No.) }\end{array}$ & River name & $\begin{array}{c}\text { Number } \\
\text { of } \\
\text { sampling } \\
\text { sites }\end{array}$ & $\begin{array}{c}\% \\
\text { negative } \\
\text { sites }\end{array}$ & $\begin{array}{c}\text { Mean } \\
\text { ammocoete } \\
\text { density per } / \mathrm{m}^{2} \\
\pm 95 \% \mathrm{CI}\end{array}$ & $\begin{array}{l}\text { Ammocoete } \\
\text { length range, } \\
\mathrm{mm}\end{array}$ & $\begin{array}{c}\text { Conservation } \\
\text { status }\end{array}$ \\
\hline LTKRE0006 (3) & Šventoji ${ }^{\star *}$ & 1 & 0 & 46 & $26-79$ & $\begin{array}{l}\text { Unfavourable- } \\
\text { inadequate }\end{array}$ \\
\hline LTKLA0007 (4) & Minija $^{*}$ & 1 & 0 & 1 & $87-89$ & $\begin{array}{c}\text { Unfavourable- } \\
\text { inadequate }\end{array}$ \\
\hline LTKRE0005 (5) & $\begin{array}{l}\text { Salantas and } \\
\text { Blendžiava }^{* *}\end{array}$ & 2 & 0 & $31.5 \pm 12.5$ & $22-142$ & Favourable \\
\hline LTPLU0011(7) & Sausdravas ${ }^{\star *}$ & 1 & 0 & 9 & $25-132$ & $\begin{array}{c}\text { Unfavourable- } \\
\text { inadequate }\end{array}$ \\
\hline LTPAS0002 (14) & Mūša ${ }^{\star *}$ & 1 & 100 & 0 & - & $\begin{array}{c}\text { Unfavourable- } \\
\text { bad }\end{array}$ \\
\hline LTUKM0002 (15) & Šventoji ${ }^{\star *}$ & 3 & 33 & $4 \pm 6.8$ & $30-134$ & $\begin{array}{c}\text { Unfavourable- } \\
\text { inadequate }\end{array}$ \\
\hline LTUKM0005 (16) & Siesartis $^{\star *}$ & 1 & 0 & 8 & $43-145$ & $\begin{array}{c}\text { Unfavourable- } \\
\text { inadequate }\end{array}$ \\
\hline LTJOA0002 (17) & Širvinta $^{\star \star}$ & 1 & 0 & 41 & $32-50$ & $\begin{array}{l}\text { Unfavourable- } \\
\text { inadequate }\end{array}$ \\
\hline LTVIN0009 (18) & Neris $^{* *}$ & 3 & 66 & $0.33 \pm 0.7$ & 61 & $\begin{array}{c}\text { Unfavourable- } \\
\text { inadequate }\end{array}$ \\
\hline LTSVE0020 (19) & Žeimena $^{*}$ & 5 & 40 & $2.8 \pm 2.9$ & $41-134$ & $\begin{array}{c}\text { Unfavourable- } \\
\text { inadequate }\end{array}$ \\
\hline LTSVE0024 (20) & Saria $^{\star *}$ & 2 & 50 & $8.5 \pm 16.6$ & $12-107$ & $\begin{array}{c}\text { Unfavourable- } \\
\text { inadequate }\end{array}$ \\
\hline LTSVE0008 (21) & $\operatorname{Mera}^{* *}$ & 2 & 50 & $4 \pm 7.8$ & $17-52$ & $\begin{array}{c}\text { Unfavourable- } \\
\text { inadequate }\end{array}$ \\
\hline LTVAR0011 (22) & Merkys* & 9 & 22 & $5.6 \pm 2.6$ & $16-140$ & $\begin{array}{c}\text { Unfavourable- } \\
\text { inadequate }\end{array}$ \\
\hline LTVAR0012 (23) & Üla $^{*}$ & 5 & 20 & $3.8 \pm 2.7$ & $67-103$ & $\begin{array}{c}\text { Unfavourable- } \\
\text { inadequate }\end{array}$ \\
\hline LTVAR0015 (24) & Derežna $^{\star *}$ & 2 & 0 & 4 & $72-109$ & $\begin{array}{c}\text { Unfavourable- } \\
\text { inadequate }\end{array}$ \\
\hline LTVAR0016 (25) & $\begin{array}{l}\text { Verseka and } \\
\text { Pasgrinda }\end{array}$ & 2 & 50 & 2.5 & $45-85$ & $\begin{array}{c}\text { Unfavourable- } \\
\text { inadequate }\end{array}$ \\
\hline
\end{tabular}

* data collected in 2008 study period

** data collected in 2012 study period 
Due to impossible discrimination between ammocoetes of $L$. planeri and L. fluviatilis they were grouped together (Gardiner, 2003), thus, giving higher density values and 'Favourable' status of $L$. planeri. The pSCI in the Mūša River was the only rated to have 'Unfavourable-bad' condition. Watershed of the Mūša River is characterized by intense anthropogenic pollution, channelization and natural habitat destruction, as well as other factors (Paukštys et al., 2011) and it is highly probable not to support healthy and abundant lamprey population. All the remaining pSCIs have been rated as complying with 'Unfavourable-inadequate' conservation status.

Marine sites and lagoons are considered important migration routes or feeding grounds, this way they are also assigned as pSCIs for L. fluviatilis and (Figure, ref. No. 1, 2), however, they cannot be assessed by widespread study methods and they are not evaluated in the current study. Large rivers usually do not hold spawning ground and considering the limited range of ammocoete dispersion during the larval stage (Staponkus et al., unpublished) are designated for conservation of migration routes rather than lamprey habitats (Figure, ref. No. $4,9,11,18)$. Our results also suggest this assumption to be correct as the larger rivers really showed the smallest population densities: the Minija River $1 \mathrm{per} / \mathrm{m}^{2}$, the Neris River $0.33 \mathrm{per} / \mathrm{m}^{2}$, the Žeimena River $2.8 \mathrm{per} / \mathrm{m}^{2}$ and the Šventoji River 4 per $/ \mathrm{m}^{2}$. However, the population density identified by Mackevičius (1969) in 1967-1968 study periods was much above the current values: in the Minija River $98 \mathrm{per} / \mathrm{m}^{2}$, the Neris River $19 \mathrm{per} / \mathrm{m}^{2}$ and the Šventoji River $42 \mathrm{per} / \mathrm{m}^{2}$. Such population density in the listed rivers could be sustained only by very good conditions in tributaries which obviously have changed over the last 40 years and lamprey population has faced a drastic decline.

The means for improvement of population status are usually inferred by construction of technical fishways on dams and weirs and reconnecting lost spawning grounds and habitats. The conventional fishways are primarily designed to effectively pass salmonids and other migratory fishes, but have little consideration of lamprey passage. The extreme inefficiency of most common fishways for L. fluviatilis migration (Foulds and Lucas, 2013) with minimal contribution to lamprey protection and conservation has been recently demonstrated. Hopefully, this can be solved by applying technical modifications to new already existing fishways.

\section{CONCLUSIONS}

At present due to dams and weirs there are isolated populations of $L$. planeri and open populations with co-occurring of both nominal species of L. planeri and L. fluviatilis.

Lamprey, especially L. fluviatilis, population in Lithuania has faced a dramatic decline in the last 40 years. Recent status for both species is mostly rated as 'Unfavourable-inadequate'. The proposed pSCIs for the protection of lamprey also incorporate other aquatic species of Community Interest or riparian habitats. From a practical point of view, this reduces expenditures for monitoring and management of such areas. However, such approach can overlook areas that are suitable for maintenance of sustaining source populations and thus contribute to actual conservation of lampreys. Therefore, we consider the need for additional conservation areas designated entirely for protection of important spawning grounds and ammocoete beds.

Conservation status in larger rivers directly depends on free access to tributaries where typically major spawning grounds are located. To reach favourable status, especially for anadromous lampreys, free access to these grounds is essential. However, there should also be taken into account specific requirements for conventional fishways as they have been shown to be completely inefficient and lacking actual conservation value.

The following measures can be insufficient to reach favourable status as natural rivers, especially small tributaries, have been altered for agricultural purposes. Changes in hydrological 
and thermal conditions also supposedly contribute to current conservation status and elimination of such effects usually is prolonged and costly with unguaranteed improvement. We consider that in order to achieve favourable conservation status the set targets could be reduced to the highest values estimated in this study and accounting for $20-30 \mathrm{per} / \mathrm{m}^{2}$.

\section{ACKNOWLEDGEMENT}

This work was funded by Ministry of Environment of the Republic of Lithuania, Contracts No. 4F08-44 and No. 4F12-111.

Received 15 January 2014 Accepted 26 March 2014

\section{References}

1. Freyhof J. Lampetra fluviatilis. In: IUCN 2013. IUCN Red List of Threatened Species. Version 2013.2. 2011a; accessed on 24 February 2014.

2. Freyhof J. Lampetra planeri. In: IUCN 2013. IUCN Red List of Threatened Species. Version 2013.2. 2011b; accessed on 24 February 2014.

3. Freyhof J. Petromyzon marinus. In: IUCN 2013. IUCN Red List of Threatened Species. Version 2013.2. 2011c; accessed on 24 February 2014.

4. Gailiušis B, Jablonskis J, Kovalenkovienè M. Lithuanian rivers: hydrography and runoff 2001; Lithuanian Energy Institute 2001; Kaunas (in Lithuanian).

5. Gardiner R. Identifying lamprey: A field key for sea, river and brook lamprey. Conserving Natura 2000 Rivers Conservation Techniques Series 2003; No. 4, English Nature, Peterborough.

6. Harvey J and Cowx I. Monitoring the River, Sea and Brook Lamprey, Lampetra fluviatilis, L. planeriand Petromyzon marinus. Conserving Natura 2000 Rivers Monitoring Series 2003; No. 5, English Nature, Peterborough.
7. Renaud CB. Lampreys of the world. An annotated and illustrated catalogue of lamprey species known to date. FAO Species Catalogue for Fishery Purposes 2011; No. 5. Rome.

8. Red Data Book of Lithuania. Rašomavičius $\mathrm{V}$ (ed.). Ministry of Environment of the Republic of Lithuania 2007; Vilnius (in Lithuanian).

9. Paukštys B, Vaitiekūnienè J, Virbickas T, Daunys D, Taminskas J, Gregorauskas M, Klimas A, Domaševičius A, Štuopis A., Drevalienè G, Valiuškevičius G, Bukantis A, Stonevičius E, Rimkus E, Kažys J, Štaras A, Povilaitis A, Punys $\mathrm{P}$, Semėnienė $\mathrm{D}$, Oskolokaitė I, Langas $\mathrm{V}$, Strazdaite I. Lietuvos vandens telkinių būklè ir ūkinès veiklos poveikis [Status and economic activity effect on water bodies of Lithuania] 2011; Vilnius (in Lithuanian).

10. Mackevičius A. River lamprey, distribution in Lithuanian waters and some of biological features 1969; Diploma thesis. Vilnius University, Vilnius (in Lithuanian).

11. Minister of Environment of the Republic of Lithuania Order No. D1-389 of the 21 July 2008 on amendments of the "Description of the criteria for the selection of the sites of Community importance (SCI)". Official Gazette 2008; No. 87-3495.

12. Torgersen CE, Close DA. Influence of habitat heterogeneity on the distribution of larval Pacific lamprey (Lampetra tridentata) at two spatial scales. Freshwat Biol 2004; 49: 614-630.

13. HELCOM. HELCOM Red List of Baltic Sea species in danger of becoming extinct. Balt Sea Environ Proc 2013; 140: 69-73.

14. Keefer ML, Clabough TC, Jepson MA, Johnson EL, Boggs CT and Caudill CC. Adult Pacific Lamprey Passage: Data Synthesis and Fishway Improvement Prioritization Tools. Technical Report 2012; Department of Fish and Wildlife Sciences, College of Natural Resources, University of Idaho.

15. Kesminas V, Švagždys A. Length and weight distribution of the river lamprey, Lampetra fluviatilis (L.), sampled in the Nemunas River Estuary. Arch Pol Fish 2010; 18: 257-260. 
16. Kesminas V, Virbickas T, Steponėnas A, Ložys L, Repečka R. European importance lampreys and fish. In: Arbačiauskas K (ed.). Fauna monitoring methods 2009a; 86-104 (in Lithuanian).

17. Kesminas V, Virbickas T, Steponènas A, Repečka R. NATURA 2000 fish species conservation in Lithuania 2009b; 2nd European Congress of Conservation Biology. Prague.

\section{Robertas Staponkus, Vytautas Kesminas}

\section{NĖGIŲ BŪKLĖS İVERTINIMAS LIETUVOS UPĖSE NATURA 2000 SAUGOMOSE TERITORIJOSE}

\section{Santrauka}

Straipsnyje apžvelgiama dviejų Lietuvoje aptinkamų nègių rūšių - upinès nègès Lampetra fluviatilis L. ir mažosios nėgès Lampetra planeri Bloch apsaugos būklè. Abi rūšys daugelyje Europos valstybių yra laikomos pažeidžiamomis, esančiomis prie išnykimo ribos ar jau išnykusiomis. Migracijos kliūtys, buveinių degradacija ir populiacijų fragmentacija yra įvardijamos kaip pagrindinès priežastys, lemiančios nėgių dabartinę ekologinę būklę. Atsižvelgiant i̇ esamą padètí, visos Europos Sajungos valstybès narès šių rūšių apsaugai privalo išskirti specialias saugomas teritorijas (SST). Šiame tyrime mes įvertinome upinių ir mažųjų négių paplitimą ir ekologinę būklę Lietuvos upèse, šių rūšiu apsaugai skirtose teritorijose (BAST). Nègių būklè nustatyta pagal Aplinkos ministerijos patvirtintą metodiką 16 teritorijų (41-oje tyrimų vietoje) pagal sesslių nėgių lervų (vingilių) gausumą ir pasiskirstymą. Tyrimų rezultatai palyginti su turimais istoriniais duomenimis, nustatyti veiksniai, turintys didžiausią ittaką nègių ekologinei būklei ir paplitimui. Pateiktos rekomendacijos dèl nègiu būklès gerinimo.

Raktažodžiai: upinè nègè, mažoji nėgè, Lampetra, BAST, NATURA 2000 
